\title{
Karakter Agronomi dan Fisiologi Varietas Cabai Merah pada Kondisi Cekaman Genangan
}

\author{
Agronomic and Physiological Characteristics of Red Chilli Varieties under Waterlogging Stress
}

\author{
Susilawati*, Rujito Agus Suwignyo, Munandar, dan Mery Hasmeda \\ Jurusan Budidaya Pertanian, Fakultas Pertanian, Universitas Sriwijaya \\ Jl. Palembang-Prabumulih Km. 32 Indralaya, Sumatera Selatan, Indonesia
}

Diterima 14 Juni 2012/Disetujui 18 Oktober 2012

\begin{abstract}
The research objective was to study the agronomic and physiological characteristics of red chilli (Capsicum annuum L.) varieties under waterlogging stress. These studies were conducted at two locations: in Palembang, South Sumatra, from February to August 2010 and in Bogor in West Java, from September to November 2010. Experiments in Palembang was using split plot design with three replications. The main plot was waterlogging treatment for 1, 2, 3 and 4 days. The subplot was red chilli varieties: Kiyo F1, Riawan, Ferosa, Bravo F1 and Laris. Experiments in Bogor was conducted without the use of experimental design; the same plant varieties were waterlogged for 2 and 4 days. The results showed that waterlogging caused root damages on all varieties. Kiyo F1 had better agronomic characters and high levels of tolerance than other varieties. The content of ethylene in all varieties increased with increasing time of waterlogging, except for Laris. In all varieties both leaf chlorophyll and tissue $N$ content tend to decline with the increase in waterlogging duration. However Bravo F1 experienced an increase in the chlorophyll content whereas Kiyo F1 had an increase in $N$ in the plant tissue.
\end{abstract}

Keywords: agronomic character, physiological character, red chili, waterlogging

ABSTRAK

Penelitian ini bertujuan untuk mengetahui pengaruh genangan terhadap karakter agronomi dan fisiologi serta tingkat toleransi beberapa varietas cabai merah. Penelitian dilakukan pada dua lokasi yaitu di Palembang Sumatera Selatan, pada bulan Februari sampai Agustus 2010 dan di Bogor Jawa Barat pada bulan September sampai November 2010. Percobaan di Palembang menggunakan rancangan petak terbagi (split plot design) dengan tiga ulangan. Petak utama adalah kondisi tercekam genangan yaitu tanaman yang tercekam genangan selama 1, 2, 3 dan 4 hari, sedangkan anak petak adalah varietas cabai merah terdiri atas Kiyo F1, Riawan, Ferosa, Bravo F1 dan Laris. Percobaan di Bogor tanpa menggunakan rancangan percobaan, menggunakan varietas yang sama dan lama genangan 2 dan 4 hari. Hasil penelitian menunjukkan bahwa perlakuan genangan menyebabkan adanya kerusakan akar pada semua varietas cabai merah. Kandungan etilen pada semua varietas meningkat sejalan dengan peningkatan waktu tergenang, kecuali pada varietas Laris. Kandungan klorofil daun dan $N$ jaringan cenderung menurun pada semua varietas, akan tetapi varietas Bravo F1 mengalami peningkatan kandungan klorofil dan varietas Kiyo F1 mengalami peningkatan kandungan Njaringan. Varietas Kiyo F1 memiliki karakter agronomi yang lebih baik dan tingkat toleransi yang tinggi dibandingkan varietas lain.

Kata kunci: cabai merah, genangan, karakter agronomi, karakter fisiologi

\section{PENDAHULUAN}

Genangan merupakan cekaman lingkungan abiotik yang menurunkan pertumbuhan dan produktivitas tanaman. Hal ini telah menjadi masalah besar di beberapa bagian dunia. Genangan sering terjadi di ekosistem dengan curah hujan yang tinggi, terutama pada tanah dengan drainase yang buruk (Visser et al., 2003). Genangan dapat dibedakan menjadi dua, pertama hanya akar tanaman yang tergenang air (waterlogging), dan kedua seluruh bagian

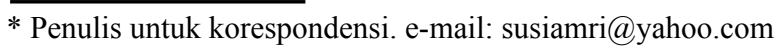

tanaman terendam air (submergence) (Shimamura et al., 2002). Sekitar $20 \%$ air dalam tanah melebihi kapasitas lapang pada kondisi tergenang akibatnya tanah kekurangan oksigen (Colmer dan Voesenek, 2009). Tanaman mampu hidup dan tumbuh pada kondisi tanah tergenang melalui adaptasi anatomi, morfologi dan mekanisme metabolik (Pourabdal et al., 2008). Cekaman genangan menyebabkan meningkatnya produksi hormon etilen pada tanaman Rumex palustris (Voesenek et al., 2003; Sairam et al., 2008).

Tanaman cabai sangat peka terhadap genangan. Tanaman cabai yang tercekam genangan satu hari menginduksi penutupan stomata lebih awal, dan peningkatan cekaman sampai enam hari menyebabkan pertumbuhan 
daun berkurang. Hal ini dikarenakan ABA dalam xilem meningkat dengan cepat seiring dengan peningkatan lama genangan (Ismail dan Davies, 1997). Hasil penelitian pada tanaman tomat menunjukkan terjadinya penurunan jumlah buah yang terbentuk dari 2.5-9.7 menjadi 0-3.15 jika lama genangan diperpanjang dari 2 hari menjadi 8 hari (Rao dan Yuncong Li, 2003). Untuk itu diperlukan penelitian yang bertujuan mengetahui pengaruh genangan terhadap karakter agronomi dan fisiologi serta tingkat toleransi beberapa varietas cabai merah.

\section{BAHAN DAN METODE}

Penelitian dilakukan pada dua lokasi yaitu di Palembang, Sumatera Selatan (bulan Februari sampai dengan Agustus 2010) dan di Bogor, Jawa Barat (September sampai dengan November 2010). Percobaan di Palembang menggunakan rancangan petak terbagi (split plot design) dengan tiga ulangan. Petak utama adalah kondisi tercekam genangan yaitu tanaman yang tercekam genangan selama 1 , 2, 3 dan 4 hari, sedangkan anak petak adalah varietas cabai merah terdiri dari Kiyo F1, Riawan, Ferosa, Bravo F1 dan Laris. Percobaan di Bogor menggunakan lama genangan 2 dan 4 hari, dengan varietas yang sama.

Penyemaian benih pada kedua lokasi dilakukan dengan cara yang sama. Benih cabai direndam dalam air selama \pm 24 jam, lalu disemai dalam baki semai ukuran 34 $\mathrm{cm} \times 25.5 \mathrm{~cm}$ x $7 \mathrm{~cm}$. Setelah $1 \mathrm{minggu}$, bibit dipindah dan dipelihara dalam polybag berukuran $14.5 \mathrm{~cm}$ x $6 \mathrm{~cm}$ selama 3 minggu.

Penanaman di Palembang, menggunakan tanah podsolik merah-kuning yang dicampur dengan pupuk kotoran ayam dengan perbandingan 2:1 (v:v). Campuran media dimasukkan ke dalam polybag berukuran $20 \mathrm{~cm}$ x 40 $\mathrm{cm}$ dengan total media sebanyak $10 \mathrm{~kg}$ dan tinggi media \pm $23 \mathrm{~cm}$. Pemupukan SP-36 dilakukan satu minggu sebelum tanam dengan dosis $150 \mathrm{~kg} \mathrm{ha}^{-1}$. Pupuk lain diaplikasikan dengan dosis $\left(\mathrm{kg} \mathrm{ha}^{-1}\right)$ urea 50, ZA 300 dan $\mathrm{KCl} 150$. Pemupukan dilakukan sebanyak tiga kali, pertama 1/3 dosis pada saat tanam, kedua $1 / 3$ dosis pada saat umur tanaman 1 bulan setelah tanam (BST) dan ketiga $1 / 3$ dosis pada saat umur tanaman 2 BST. Penanaman di Bogor menggunakan tanah latosol yang dicampur dengan kotoran ayam dengan perbandingan 2:1 (v:v). Campuran media dimasukkan ke dalam polybag berukuran $10 \mathrm{~cm}$ x $30 \mathrm{~cm}$ dengan total media sebanyak $5 \mathrm{~kg}$ dan tinggi media $\pm 18 \mathrm{~cm}$. Pemupukan SP-36 dilakukan satu minggu sebelum tanam dengan dosis 100 $\mathrm{kg} \mathrm{ha}^{-1}$. Pupuk lain diaplikasikan dengan dosis $\left(\mathrm{kg} \mathrm{ha}^{-1}\right)$ urea 100, ZA 200 dan $\mathrm{KCl} 100$. Pemupukan diberikan sebanyak dua kali, pertama $1 / 2$ dosis pada saat tanam dan tahap kedua $1 / 2$ dosis pada saat umur tanaman $1 \mathrm{BST}$.

Perlakuan genangan untuk kedua lokasi dilakukan pada saat umur tanaman 4 MST dengan cara merendam polybag sampai ke permukaan media (tinggi air genangan \pm $3 \mathrm{~cm}$ dari permukaan media). Pada percobaan di Palembang, genangan diaplikasikan menggunakan bak genangan yang terbuat dari plastik terpal yang diberi penyangga siku besi dengan ukuran $10 \mathrm{~m} \times 8 \mathrm{~m} \times 0.3 \mathrm{~m}$. Pada percobaan di
Bogor, menggunakan bak genangan berukuran ukuran $4 \mathrm{~m}$ x $1 \mathrm{~m}$ x $0.25 \mathrm{~m}$ yang terbuat dari plastik hitam yang disangga dengan papan.

Pengamatan di Palembang terdiri dari karakter agronomi dan fisiologi. Karakter agronomi meliputi kemampuan tanaman bertahan hidup (hari), jumlah tanaman hidup (\%), tinggi tanaman (cm), umur berbunga (hari), jumlah cabang, rasio tajuk:akar, jumlah buah per tanaman, bobot buah per tanaman per periode panen dan total bobot buah per tanaman, dan karakter fisiologi meliputi kandungan klorofil ( $\left.\mathrm{mg} \mathrm{dm}^{-2}\right)$ dan nitrogen $(\mathrm{N})$ jaringan $(\mathrm{g}$ $\mathrm{kg}^{-1}$ ). Penetapan kandungan klorofil menggunakan metode perendaman menggunakan metanol (Hall dan Rao, 1987). Secara umum, kandungan klorofil ditetapkan dengan merendam daun segar (ukuran $2 \mathrm{~cm} \mathrm{x} 2 \mathrm{~cm}$ ) dalam metanol $10 \mathrm{~mL}$ selama 48 jam, kemudian ditentukan absorbannya dengan spektrofotometer pada panjang gelombang 650 dan $665 \mathrm{~nm}$. Nitrogen jaringan ditetapkan dengan metode Kjedahl, yaitu $0.1 \mathrm{~g}$ sampel kering oven ditambah $5 \mathrm{~mL}$ asam sulfat pekat dipanaskan dalam ruang asam. Destilasi menggunakan asam borak dan indikator. Kemudian larutan dititrasi dengan asam sulfat $0.01 \mathrm{~N}$ sampai berwarna merah (Lorenz, 1978). Analisa kandungan klorofil dan $\mathrm{N}$ jaringan dilakukan di Laboratorium Fisiologi Fakultas Pertanian Universitas Sriwijaya, Ogan Ilir, Sumatera Selatan.

Penentuan kategori toleransi tanaman terhadap cekaman genangan dimulai dengan mengkategorikan satu karakter agronomi yang sama pada semua varietas berdasarkan standar deviasi (std) yang dibedakan menjadi tiga kriteria, yaitu:

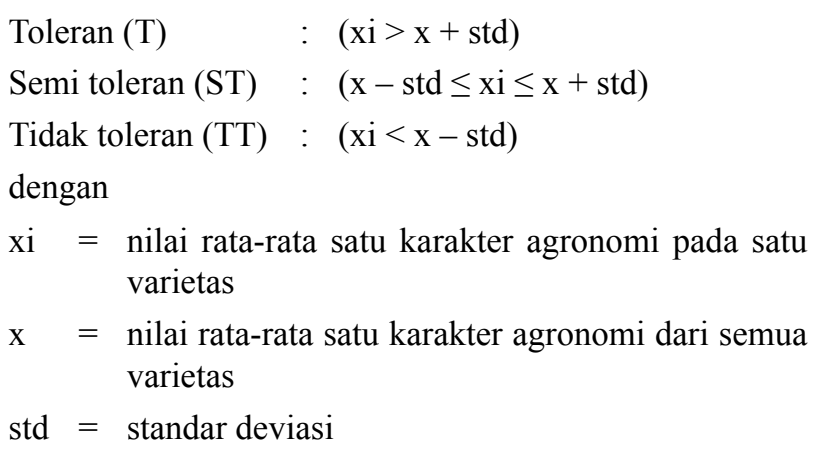

Kriteria yang didapat pada satu varietas dijumlahkan. Bila satu varietas dominan memiliki kriteria toleran atau semi toleran dari jumlah karakter disebut toleran atau semi toleran dan tidak toleran bila memiliki kriteria tidak toleran yang lebih dominan diantara semua varietas (Munir, 2008). Data karakter agronomi dianalisis secara statistik menggunakan program Excel dan SPSS 16.0. Untuk mengetahui respon akibat genangan pada beberapa varietas digunakan uji ortogonal polinomial. Data karakter fisiologi tidak dianalisis secara statistik, hanya ditampilkan dalam bentuk tabulasi.

Pengamatan di Bogor berupa karakter fisiologi yang terdiri dari kandungan ACC (asam 1-aminocyclopropane1-carboxylic acid) dan etilen. Bahan untuk analisa ACC dan etilen diambil contoh akar segar yang dipotong dari leher akar. Akar digerus dan diambil $1 \mathrm{~g}$ untuk diekstrak 
dalam $30 \mathrm{~mL}$ aseton pada suhu $60^{\circ} \mathrm{C}$ selama 1 jam. Residu kering hasil evaporasi dilarutkan dalam $3 \mathrm{~mL}$ air dan $2 \mathrm{~mL}$ kloroform. Larutan diinjeksi dalam botol melalui tutup karet dan diinkubasi selama 18 jam. Pengukuran gas dengan Gas Chromatograph HITACHI 263-50 mengikuti metode Lizada dan Yang (1979). Untuk analisis kandungan etilen, sampel akar segar dipotong dari leher akar, dimasukkan dalam tabung erlenmeyer yang ditutup dengan karet lalu diinkubasi selama 6 jam. Pengukuran gas etilen dilakukan menggunakan Gas Chromatograph HITACHI 263-50. Analisis ACC dan etilen dilakukan di Laboratorium Pengujian Balai Besar Pasca Panen Cimanggu Bogor, Jawa Barat. Data ACC dan etilen tidak dianalisis secara statistik, hanya ditampilkan dalam bentuk tabulasi. Akar tanaman yang telah digenangi selama 4 hari, selain dianalisis ACC dan etilen juga diamati anatominya. Akar segar dipotong dibawah mikroskop stereo binokuler dan pengamatan anatomi menggunakan mikroskop trinokuler BX 51. Pengamatan dilakukan di Laboratorium Mikroteknik Departemen Agronomi dan Hortikultura, IPB, Bogor.

\section{HASIL DAN PEMBAHASAN}

\section{Anatomi Akar}

Akar cabai yang digenangi selama 4 hari mengalami kerusakan di sebagian atau seluruh jaringan penyusun akar (epidermis, korteks dan endodermis). Kerusakan akar pada varietas Kiyo F1 dan Riawan hanya terjadi di bagian endodermis dimana sel-selnya membusuk (warna hitam), sedangkan pada varietas Ferosa, Bravo F1 dan Laris kerusakan terjadi pada bagian epidermis, korteks dan endodermis (Gambar 1). Adanya bagian akaryang membusuk dan hancur dapat mengganggu proses masuknya air dan hara ke dalam jaringan akar. Secara morfologi, kerusakan jaringan akar ditandai dengan warna akar yang menghitam pada bagian epidermis, korteks dan endodermis. Dijelaskan oleh Rao dan Li (2003), salah satu respon tanaman cabai akibat genangan adalah ujung akar menghitam.

Rendahnya oksigen akibat genangan menyebabkan energi yang dihasilkan oleh akar rendah. Pada sel tanaman yang menerima oksigen cukup oksidasi karbohidrat terjadi dalam 3 tahap. Tahap pertama, konversi 1 molekul glukosa menghasilkan 2 molekul asam piruvat, 2 ATP dan $2 \mathrm{NADH}_{2}$ (glikolisis). Tahap kedua, oksidasi satu molekul asam piruvat ke karbondioksida, 1 ATP dan $5 \mathrm{NADH}_{2}$ (siklus Krebs). Tahap ketiga, setiap $\mathrm{NADH}_{2}$ akan digunakan untuk sintesa 3 molekul ATP melalui rantai sitokrom dari $\mathrm{NADH}_{2}$ ke oksigen dengan melepaskan air. Respirasi aerobik dari 1 molekul glukosa menghasilkan 38 molekul ATP. Bila kondisi tergenang, rantai sitokrom terputus karena tidak ada oksigen yang menyebabkan akumulasi $\mathrm{NADH}_{2}$ dan tertekannya siklus Krebs. Rendahnya oksigen akibat genangan menyebabkan energi yang dihasilkan oleh akar rendah. Energi yang rendah akibat dari proses fosforilasi oksidatif penghasil adenosine triphospat (ATP) terhenti, tetapi beberapa ATP dapat diproduksi dalam glikolisis tergantung pada proses pembentukan kembali NAD + (konversi piruvat menjadi etanol). Namun, produksi ATP melalui glikolisis lebih rendah dibandingkan proses fosforilasi oksidatif (Gibss dan Greenway, 2003). Rendahnya energi menyebabkan respirasi akar terhambat akibatnya pertumbuhan akar juga terhambat.

\section{Karakter Agronomi}

Peningkatan lama genangan menyebabkan penurunan kemampuan bertahan dan jumlah tanaman hidup dengan persamaan linier negatif (Gambar 2 dan 3). Kemampuan bertahan hidup varietas yang diuji lebih tinggi pada genangan satu hari dan lebih rendah pada genangan empat hari, walaupun fluktuasi perubahannya tidak mengikuti pola peningkatan lamanya genangan. Akibat genangan empat hari, kemampuan bertahan dan jumlah tanaman hidup varietas Kiyo F1 lebih tinggi dibandingkan empat varietas lain. Keadaan tersebut didukung oleh kondisi akar, dimana pada varietas Kiyo F1 kerusakan akar hanya sebagian dari endodermis. Disamping itu, terlihat adanya rongga-rongga sel korteks yang besar, hal ini mengindikasikan adanya proses pembentukan aerenkima (Voesenek et al., 2006).

Daun-daun pada tanaman yang tergenang pada hari ketiga mengalami kelayuan. Secara morfologi daun-daun layu akibat akar yang membusuk dan hancur. Prosesnya adalah akar tidak mampu menyerap air dan unsur hara khususnya $\mathrm{N}$, sehingga kebutuhan air dan $\mathrm{N}$ tajuk tidak terpenuhi akibatnya daun layu dan menguning. Hasil

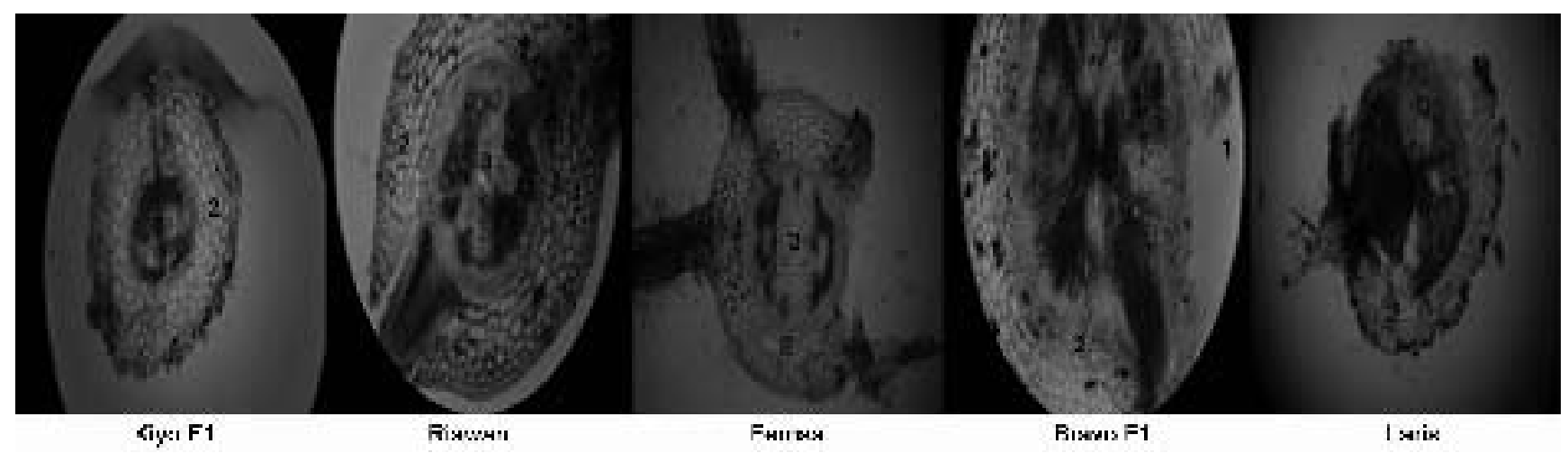

Gambar 1. Warna hitam bagian endodermis yang membusuk pada Kiyo F1 dan Riawan serta bagian epidermis, korteks dan endodermis yang hancur pada Ferosa, Bravo F1 dan Laris; $1=$ epidermis; $2=$ korteks; $3=$ endodermis 


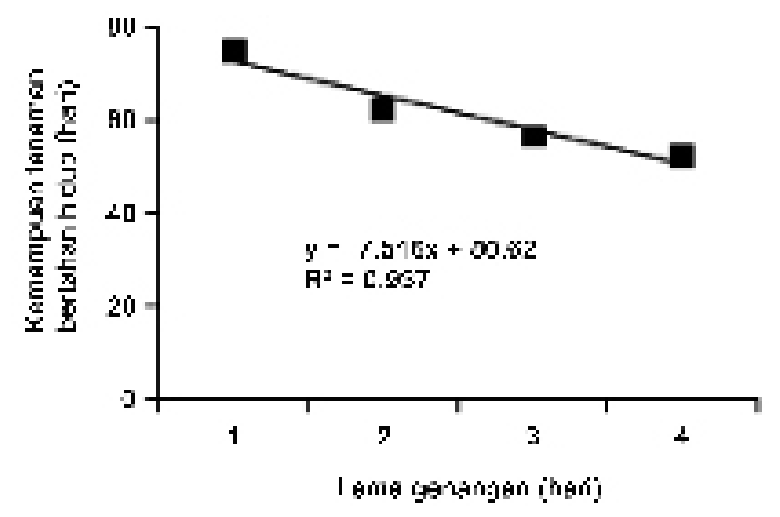

Gambar 2. Kemampuan tanaman bertahan hidup berdasarkan lama genangan

penelitian pada tanaman kedelai menunjukkan bahwa tanaman yang tergenang selama satu sampai dua hari tidak menyebabkan pengurangan hasil, tetapi tanaman yang tergenang selama tiga hari mengakibatkan daun klorosis, gugur, pertumbuhan terhenti dan akhirnya tanaman mati (Boru et al., 2003). Hasil penelitian lain pada tanaman tebu menunjukkan bahwa tanaman tebu yang tergenang selama dua hari tidak mengalami kehilangan hasil yang signifikan dibandingkan tanaman yang tergenang selama tujuh hari (Glaz et al., 2004).

Secara fisiologi, daun-daun layu mengindikasikan ketidakmampuan tanaman untuk mengimbangi proses transpirasi. Kekurangan air dalam tubuh tanaman terjadi akibat kekurangan oksigen pada akar. Menurut Sairam et al. (2009) kekurangan oksigen akibat genangan merupakan faktor pembatas pertumbuhan dan produktivitas tanaman. Kekurangan oksigen menggeser metabolisme energi dari aerob menjadi anaerob sehingga berpengaruh kurang

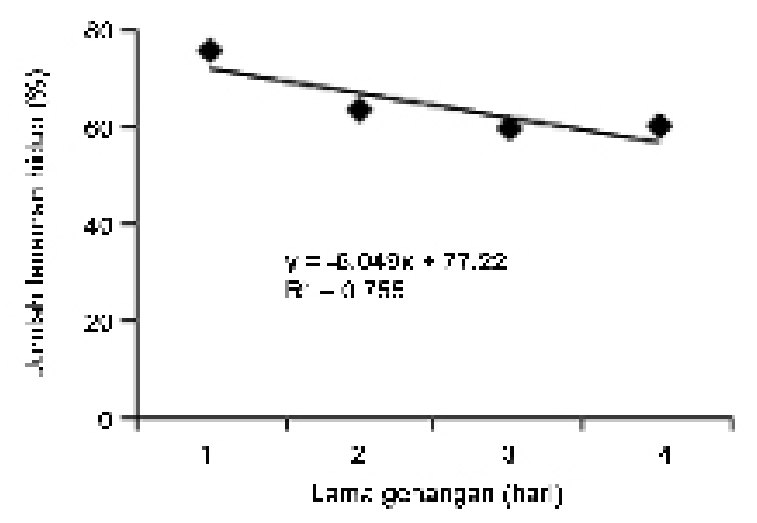

Gambar 3. Jumlah tanaman hidup berdasarkan lama genangan

baik terhadap serapan air. Akibatnya tanaman kekurangan air walaupun tersedia banyak air. Pengaruh lain akibat kekurangan oksigen pada akar diteliti oleh Jackson (2002) yang menunjukkan bahwa penghentian oksigen selama 4 sampai 6 jam di akar tomat dapat memacu pemanjangan sel pada daun yang dikenal dengan epinasti.

Pengaruh genangan terhadap tanaman cabai juga tercermin pada jumlah cabang, jumlah buah dan bobot buah (Gambar 4, 5 dan 6). Jumlah cabang pada semua varietas yang diuji tertinggi pada genangan satu hari. Akibat genangan empat hari jumlah cabang tertinggi didapat pada varietas Laris, namun jumlah cabang yang tinggi tersebut tidak didukung oleh kondisi akar akibatnya jumlah dan bobot buah yang terbentuk lebih rendah dibandingkan varietas Kiyo F1. Pada varietas Riawan, walaupun kondisi akar baik namun jumlah cabang yang terbentuk rendah dibandingkan empat varietas lain. Akibatnya, jumlah dan bobot buah yang dihasilkan juga rendah. Untuk varietas Ferosa dan Bravo F1

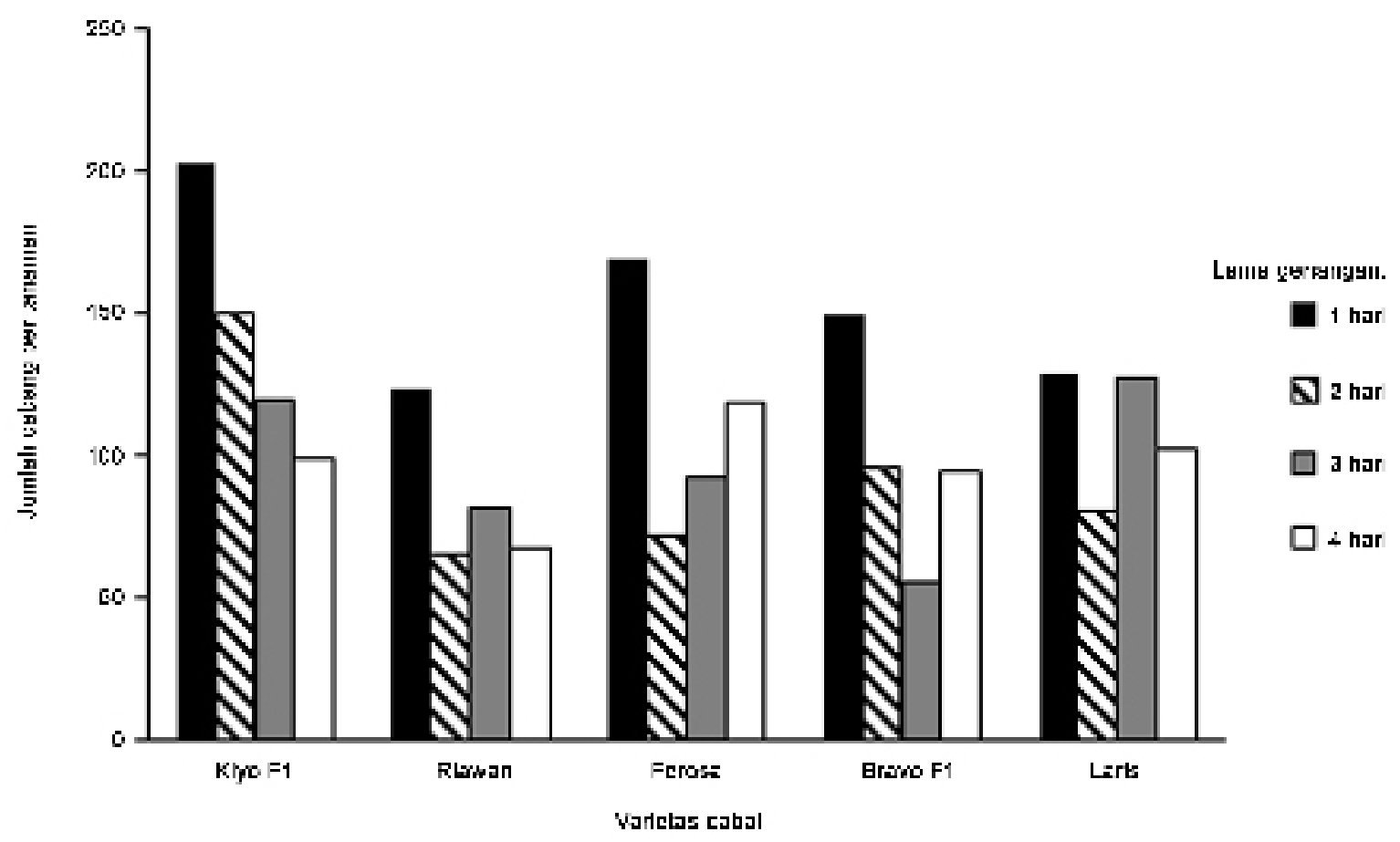

Gambar 4. Jumlah cabang tanaman tiap varietas cabai berdasarkan lama genangan 


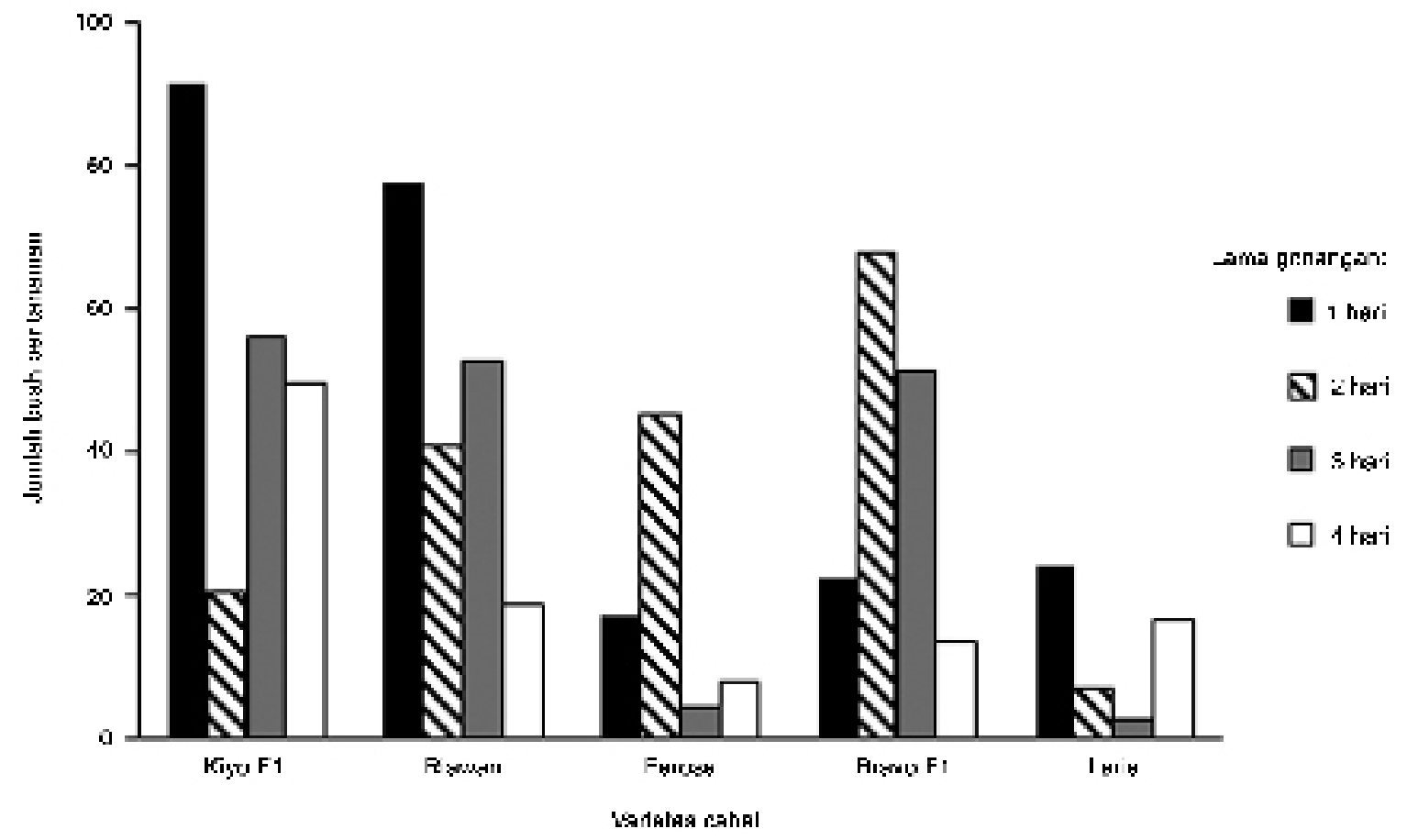

Gambar 5. Jumlah buah tiap varietas cabai berdasarkan lama genangan

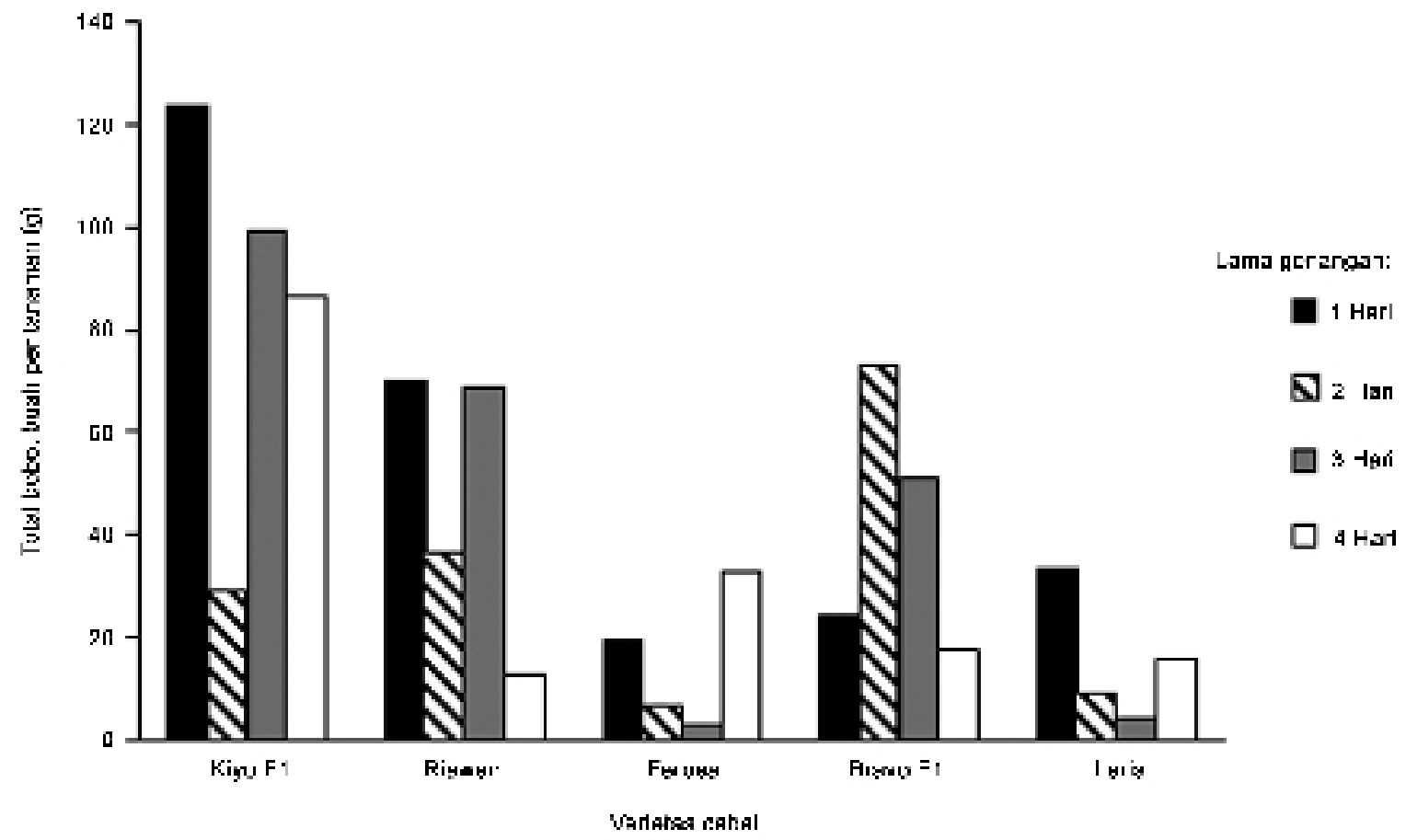

Gambar 6. Bobot buah tiap varietas cabai berdasarkan lama genangan

sama seperti varietas Laris jumlah cabang yang terbentuk tidak didukung oleh kondisi akar sehingga jumlah dan berat buah lebih rendah dibandingkan Kiyo F1.

Berdasarkan beberapa karakter agronomi, varietas Kiyo F1 tergolong toleran, varietas Ferosa, Bravo F1, dan Laris tergolong semi toleran, sedangkan varietas Riawan tergolong tidak toleran (Tabel 1). Varietas Kiyo F1 yang tergolong toleran memiliki sistem perakaran yang baik.
Zhou et al. (2007) melaporkan bahwa pada tanaman barley toleran genangan sistem perakarannya lebih baik karena adanya pembentukan aerenkima, sedangkan pada tanaman yang tidak toleran terjadi kerusakan akar. Akan tetapi varietas Riawan yang tergolong tidak toleran juga memiliki sistem perakaran yang baik seperti Kiyo F1. Hal ini menunjukkan bahwa varietas toleran genangan ditandai dengan sedikitnya kerusakan akar pada bagian endodermis, 
Tabel 1. Tingkat toleransi varietas cabai merah menggunakan karakter agronomi berdasarkan standar deviasi

\begin{tabular}{|c|c|c|c|c|c|}
\hline \multirow{2}{*}{ Karakter agronomi } & \multicolumn{5}{|c|}{ Varietas } \\
\hline & Kiyo F1 & Riawan & Ferosa & Bravo F1 & Laris \\
\hline \multicolumn{6}{|l|}{ Kemampuan tanaman } \\
\hline bertahan hidup (hari) & 58.72 & 73.36 & 64.31 & 50.5 & 61.83 \\
\hline$(61.74 \pm 8.32)$ & ST & $\mathrm{T}$ & ST & TT & ST \\
\hline Jumlah tanaman hidup & 61.11 & 75.00 & 61.11 & 44.45 & 66.67 \\
\hline$(61.67 \pm 11.18)$ & ST & $\mathrm{T}$ & ST & TT & ST \\
\hline Tinggi tanaman $(\mathrm{cm})$ & 46.41 & 45.22 & 49.24 & 46.5 & 48.24 \\
\hline$(47.12 \pm 1.6)$ & ST & TT & $\mathrm{T}$ & ST & ST \\
\hline Umur berbunga (hari) & 35.61 & 42.03 & 36.67 & 35.38 & 39.11 \\
\hline$(37.80 \pm 2.77)$ & ST & TT & ST & ST & ST \\
\hline Jumlah cabang & 130.58 & 73.75 & 105.67 & 75.33 & 109.92 \\
\hline$(99.05 \pm 24.28)$ & $\mathrm{T}$ & TT & ST & ST & ST \\
\hline Rasio tajuk:akar & 9.36 & 5.96 & 7.93 & 7.55 & 5.81 \\
\hline$(7.32 \pm 1.48)$ & $\mathrm{T}$ & ST & ST & ST & TT \\
\hline Jumlah buah tanaman ${ }^{-1}$ & 52.75 & 42.58 & 13.58 & 32.08 & 10.75 \\
\hline$(30.35 \pm 18.16)$ & $\mathrm{T}$ & ST & ST & ST & TT \\
\hline Bobot buah tanaman ${ }^{-1}$ & 9.14 & 6.13 & 3.09 & 5.41 & 3.12 \\
\hline $\operatorname{panen}^{-1}(5.34 \pm 2.51)(\mathrm{g})$ & $\mathrm{T}$ & ST & ST & ST & ST \\
\hline Total bobot buah tanaman ${ }^{-1}(\mathrm{~g})$ & 82.09 & 43.82 & 12.60 & 34.13 & 13.04 \\
\hline$(37.14 \pm 28.54)$ & $\mathrm{T}$ & ST & ST & ST & ST \\
\hline \multirow[t]{3}{*}{ Total kriteria } & $5 \mathrm{~T}$ & $2 \mathrm{~T}$ & $1 \mathrm{~T}$ & $0 \mathrm{~T}$ & $0 \mathrm{~T}$ \\
\hline & $4 \mathrm{ST}$ & $4 \mathrm{ST}$ & $8 \mathrm{ST}$ & $7 \mathrm{ST}$ & $7 \mathrm{ST}$ \\
\hline & $0 \mathrm{TT}$ & $3 \mathrm{TT}$ & $0 \mathrm{TT}$ & $2 \mathrm{TT}$ & $2 \mathrm{TT}$ \\
\hline
\end{tabular}

Keterangan: Total kriteria : 0-9 = jumlah kriteria; $\mathrm{T}=$ toleran; $\mathrm{ST}=$ semi toleran; $\mathrm{TT}=$ tidak toleran

memiliki kemampuan tumbuh dan berproduksi tinggi (jumlah dan bobot buah). Kriteria lain varietas toleran adalah kemampuan untuk tumbuh dan berproduksi. Menurut Van Toai et al. (2001), toleransi terhadap genangan merupakan suatu kemampuan tanaman untuk mempertahankan hasil pada kondisi tergenang, walaupun hasilnya tidak optimal. Pendapat ini mendukung Kiyo F1 sebagai varietas toleran genangan. Sedangkan varietas rentan (tidak toleran) akan mengalami gangguan fisiologi akibat genangan sehingga mempengaruhi pertumbuhan baik pada fase vegetatif maupun generatif (Ezin et al., 2010).

\section{Karakter Fisiologi}

Penurunan ACC dan peningkatan etilen sejalan dengan peningkatan lama genangan mengindikasikan adanya oksigen yang merubah ACC menjadi etilen (Tabel 2). Kondisi ini menggambarkan adanya pertumbuhan akar karena ketersediaan oksigen. Menurut Bradford (2008) ACC merupakan prekusor etilen, perubahan ACC menjadi etilen tergantung ketersediaan oksigen dan dikatalis oleh enzim ACC oksidase. Hasil penelitian Peeters et al. (2002), pada tanaman Rumex palustri menunjukkan bahwa genangan selama satu jam mengakibatkan peningkatan konsentrasi etilen 20 kali dari $0.05 \mu \mathrm{L} \mathrm{L}^{-1}$ menjadi $1.0 \mu \mathrm{L}$ $\mathrm{L}^{-1}$ dibandingkan yang tidak tergenang. Perubahan ACC dan etilen berkorelasi dengan kerusakan akar, pada varietas Kiyo F1 dan Riawan sangat didukung oleh kondisi akar yang tidak mengalami kerusakan dibandingkan Ferosa, Bravo F1 dan Laris.

Perubahan kandungan klorofil dan $\mathrm{N}$ jaringan dengan peningkatan lama genangan mengalami flukstuasi untuk semua varietas yang diuji, kecuali kandungan klorofil untuk varietas Ferosa yang menurun sejalan dengan peningkatan lama genangan (Tabel 3). Genangan selama 4 hari pada varietas Kiyo F1, Riawan dan menyebabkan penurunan kandungan klorofil. Kandungan $\mathrm{N}$ jaringan menurun untuk semua varietas kecuali Kiyo F1. Hubungan perubahan kandungan klorofil dan $\mathrm{N}$ jaringan dengan kondisi akar tercermin pada varietas Kiyo F1. Akar Kiyo F1 relatif mengalami kerusakan yang lebih sedikit dan tidak hancur, hal ini sangat mendukung tanaman dalam menyerap air dan unsur hara untuk proses fotosintesis. Disamping itu, tingginya $\mathrm{N}$ jaringan mencerminkan adanya konsentrasi protein yang tinggi. Protein yang paling banyak dijumpai adalah Rubisco, yang berperan sebagai katalisator dalam 
fiksasi $\mathrm{CO}_{2}$ untuk proses fotosintesis. Menurut Irfan et al. (2010) genangan dapat mengurangi aktivitas Rubisco dan kemampuan fotosintesis sel mesofil. Hasil penelitian pada tanaman kedelai menunjukkan bahwa kadar $\mathrm{N}$ total tanaman yang tinggi mencerminkan kemampuan tanaman untuk mempertahankan serapan $\mathrm{N}$, melakukan reduksi nitrat dan fiksasi $\mathrm{N}$ simbiosis yang tinggi (Komariah et al., 2004).

Tabel 2. Kandungan ACC dan etilen pada akar berdasarkan varietas dan lama genangan

\begin{tabular}{|c|c|c|c|c|}
\hline \multirow[t]{2}{*}{ Varietas } & \multicolumn{2}{|c|}{ Lama genangan } & \multicolumn{2}{|c|}{ Lama genangan } \\
\hline & 2 hari & 4 hari & 2 hari & 4 hari \\
\hline & \multicolumn{2}{|c|}{.. $\mathrm{ACC}\left(\mu \mathrm{L} \mathrm{L}^{-1}\right)}$. & \multicolumn{2}{|c|}{...Etilen $\left(\mu \mathrm{L} \mathrm{L}^{-1}\right)$. } \\
\hline Kiyo F1 & 1.02 & 0.95 & 0.31 & 0.35 \\
\hline Riawan & 1.08 & 1.00 & 0.18 & 0.31 \\
\hline Ferosa & 0.90 & 1.16 & 0.42 & 0.53 \\
\hline Bravo F1 & 0.96 & 1.15 & 0.39 & 0.42 \\
\hline Laris & 1.12 & 0.87 & 0.51 & 0.42 \\
\hline
\end{tabular}

Tabel 3. Kandungan klorofil dan $\mathrm{N}$ jaringan berdasarkan varietas dan lama genangan

\begin{tabular}{|c|c|c|c|c|}
\hline \multirow{2}{*}{ Varietas } & \multicolumn{4}{|c|}{ Lama genangan } \\
\hline & 1 hari & 2 hari & 3 hari & 4 hari \\
\hline & \multicolumn{4}{|c|}{...Klorofil $\left(\mathrm{mg} \mathrm{dm}^{-2}\right)}$. \\
\hline Kiyo F1 & 79.9 & 91.03 & 80.73 & 76.33 \\
\hline Riawan & 53.98 & 56.63 & 77.18 & 23.00 \\
\hline Ferosa & 107.55 & 91.83 & 79.03 & 74.25 \\
\hline Bravo F1 & 96.53 & 89.85 & 108.38 & 102.83 \\
\hline \multirow[t]{2}{*}{ Laris } & 77.79 & 90.73 & 77.1 & 84.2 \\
\hline & \multicolumn{4}{|c|}{... $\mathrm{N}$ jaringan $\left(\mathrm{g} \mathrm{kg}^{-1}\right)}$. \\
\hline Kiyo F1 & 31.78 & 22.28 & 31.78 & 63.42 \\
\hline Riawan & 34.72 & 28.00 & 21.00 & 22.82 \\
\hline Ferosa & 26.32 & 17.36 & 23.66 & 22.84 \\
\hline Bravo F1 & 27.02 & 4.34 & 24.92 & 22.96 \\
\hline Laris & 27.44 & 25.20 & 15.12 & 32.48 \\
\hline
\end{tabular}

\section{KESIMPULAN}

Cekaman genangan menyebabkan kerusakan akar dengan tingkat kerusakan yang berbeda pada semua varietas yang diuji. Kerusakan akar berkorelasi dengan karakter agronomi dan fisiologi. Berdasarkan karakter agronomi yang diamati, varietas Kiyo F1 terkategori toleran, varietas Ferosa, Bravo F1 dan Laris terkategori semi toleran, dan varietas Riawan terkategori tidak toleran. Varietas toleran genangan ditandai dengan sedikitnya kerusakan akar pada bagian endodermis, serta menghasilkan jumlah dan bobot buah tertinggi. Peningkatan etilen terjadi seiring dengan meningkatnya lama genangan dan tidak berkorelasi dengan toleransi tanaman cabai terhadap cekaman genangan. Tingginya kandungan $\mathrm{N}$ jaringan merupakan indikator karakter fisiologi pada tanaman cabai toleran genangan.

\section{UCAPAN TERIMA KASIH}

Ucapan terima kasih disampaikan kepada Direktorat Jenderal Pendidikan Tinggi, Kementrian Pendidikan Nasional yang telah mendanai penelitian ini melalui program Hibah Doktor tahun anggaran 2010.

\section{DAFTAR PUSTAKA}

Boru, G, T.T. Van Toai. J. Alves, D. Hua. M. Knee. 2003. Response of soybeans to oxygen deficiency and elevated root-zone carbondioxide concentration. Ann. Bot. 91:447-453.

Bradford, K.J. 2008. Shang Fa Yang: Pioneer in plant ethylene biochemistry. Plant Sci. 172:2-7. 
Colmer, T.D., L.A.C.J. Voesenek. 2009. Flooding tolerance: suites of plant traits in variable environments. Funct. Plant Biol. 36:665-681.

Ezin, V., R. De la Pena, A. Ahanchede. 2010. Flooding tolerance of tomato genotypes during vegetative and reproductive stages. Braz. J. Plant Physiol. 22:131142.

Gibbs, J., H. Greenway. 2003. Mechanisms of anoxia tolerance in plants. I. Growth, survival and anaerobic catabolism. Funct. Plant Biol. 30:1-47.

Glaz, B., D.R. Morris, S.H. Daroub. 2004. Periodic flooding and water table effects on two sugarcane genotypes. Agron. J. 96:832-838.

Hall, D.O., K.K. Rao. 1987. Photosynthesis. $4^{\text {th }}$ ed King's College, University of London, London.

Irfan, M., S. Hayat, Q. Hayat. 2010. Physiological and biochemical changes in plants under waterlogging. Protoplasma 24:3-17.

Ismail, M.R., W.J. Davies. 1997. Reduction in leaf growth and stomatal conductance of capsicum (Capsicum annuum) grown in flooded soil and its relation to abscisic acid. Pertanika J. Trop. Agric. Sci. 20:101106.

Jackson, M.B. 2002. Long-distance signalling from roots to shoots assessed: the flooding story. J. Exp. Bot. 53:175-181.

Komariah, A., A. Baihaki, R. Setiamihardja. 2004. Hubungan antara aktivitas nitrat reduktase, kadar $\mathrm{N}$ total dan karakter penting lainnya dengan toleransi tanaman kedelai terhadap genangan. Zuriat 15:163169.

Lizada M.C.C., S.F. Yang. 1979. A simple sensitive assay for 1-aminocyclopropane-1-carboxylic acid. Anal. Biochem. 100:140-145.

Lorenz, O.A. 1978. Potential nitrate level in edible plant parts. p. 201-219. In D.R. Nielsen. J. G. MacDonald $(E d s$.$) Nitrogen in The Environment. Academic$ Press, New York.

Munir, S. 2008. Statistik I: Ukuran Variasi (Dispersi). Bahan Ajar. Pusat Pengembangan Bahan Ajar. Fakultas Ekonomi, Universitas Mercu Buana, Jakarta.
Peeters,A.J.M., C.H. Cox., J.J. Benschop., R.A.M. Vreeburg., J. Bou, L.A.C.J. Voesenek. 2002. Submergence research using Rumex palustris as a model: looking back and going forward. J. Exp. Bot. 53:391-398.

Pourabdal, L., R. Heidary, T. Farboodnia. 2008. The effect of flooding stress on induction of oxidative stress and antioxidant enzymes activity in Zea mays L. seedlings. Res. J. Biol. Sci. 3:391-493.

Rao, R., Y. Li. 2003. Management of flooding effets on growth of vegetable and selected field crops. Hortechnol. 13:610-616.

Sairam R, K., D. Kumutha, K. Ezhilmathi, P.S. Deshmukh, G.C. Srivastava. 2008. Physiology and biochemistry of waterlogging tolerance in plants Biol. Plantarum 52:401-412.

Sairam, R.K., D. Kumutha, K. Ezhilmathi. 2009. Waterlogging tolerance: nonsymbiotic haemoglobinnitric oxide homeostatis and antioxidants. Curr. Sci. 96:674-682.

Shimamura, S., T. Mochizuki, Y. Nada, M. Fukuyama. 2002. Secondary aerenchyma formation and its relation to nitrogen fixation in root nodules of soybean plant (Glycine max) grown under flooded condition. Plant Prod. Sci. 5:294-300.

Van-Toai, T.T., K. Steven, St. Martin, K. Chase, G. Boru, V. Schnipke, A.F. Schmitthenner, K.G. Lark. 2001. Identification of a QTL associated with tolerance of soybean to soil waterlogging. Crop Sci. 41:12471252.

Visser, E.J.W., L.A.C.J. Voesenek., B.B. Vartapetian, M.B. Jackson. 2003. Flooding and plant growth. Ann. Bot. 91:107-109.

Voesenek, L.A.C.J., J.J. Benshop, J. Bou, M.C.H. Cox, H.W. Groeneveld, F.F. Millenaar, R.A.M. Vreeburg, A.J. Peeters. 2003. Interaction between plant hormones regulate submergence-induced shoot elongation in the flooding-tolerant dicot Rumex palustris. Ann. Bot. 91:205-211.

Voesenek, L.A.C.J., T.D. Colmer, R. Pierik, F.F. Millenaar, A.J.M. Peeters. 2006. How plants cope with complete submergence. New Phytol. 170:213-226.

Zhou, M.X., H.B. Li, N.J. Mendham. 2007. Combining ability of waterlogging tolerance in barley. Crop Sci. 47:278-284. 